\title{
黄河口滨海湿地水文连通对大型底栖动物 生物连通的影响
}

\author{
王新艳, 间家国, 白军红, 崔保山 \\ (北京师范大学环境学院,水环境模拟国家重点实验室,北京 100875)
}

\begin{abstract}
摘要: 滨海湿地处于海陆的交错地带, 在人类活动和气候变化的双重作用下导致湿地水文连 通受阻。选取黄河口滨海湿地三条水文连通强度差异明显的潮沟, 调查不同潮沟的大型底栖 动物群落, 分析水文连通强度对大型底栖动物分布和生物多样性的影响。结果表明: 记录到的 大型底栖动物共有 52 种, 优势类群为多毛类和软体动物; 总体来看随着水文连通强度的增强, 大型底栖动物的总密度呈上升趋势; 中等水文连通强度的区域,生物多样性较高; 大型底栖动 物不同类群的数量和分布对水文连通引起的环境因子变化的响应也有很大的差异, 多毛类和 寡毛类在水文连通弱的区域占优势, 软体动物在水文连通较强营养物质含量丰富的区域占优 势, 甲壳类在靠近潮沟源头水文连通最强的区域占优势。
\end{abstract}

关键词：滨海湿地;水文连通;大型底栖动物;生物连通

滨海湿地处于海陆的交错地带，位于咸淡水的交汇处，在海陆的共同作用下，生境 条件复杂、物种多样性丰富, 具有重要的生态服务功能 ${ }^{[-2]}$ 。然而近年来, 在人类活动和 气候变化的双重作用下，滨海湿地面积逐渐减小，湿地的水文连通受阻，导致了一系列 的生态环境问题 ${ }^{[3-5]}$ 。

水文连通是滨海湿地重要的物理过程, 是湿地斑块间物理、化学和生物连通的媒 介，在空间上主要包括源头一河口的纵向连通，河漫滩/洪泛区一河道的横向连通以及河 流地表水一地下水的垂向连通 ${ }^{[6,18]}$ 。水文连通影响着湿地重要环境因子的变化, 影响着生 物的定居、迁移扩散和繁殖等行为，进而影响着湿地的生物连通性 ${ }^{[7-8]}$ 。大型底栖动物是 湿地生态系统的重要组成部分，是食物链中的一个关键环节 ${ }^{[9-10]}$ 。由于大型底栖动物区域 性强、迁移能力弱, 且对环境条件的变化比较敏感, 通常将其作为滨海湿地生态结构与 功能完整性的关键指示指标，其群落结构的变化特征将直接反映生态系统的稳定性与变 异性 ${ }^{[1]}$ 。目前，关于滨海湿地大型底栖动物的研究大多以水体盐度、含沙量和土壤理化 性质等环境因子对群落分布以及生物多样性的影响为主 ${ }^{[12-15]}$, 这些因素实质上是由水文连 通变化引起的。然而关于水文连通变化在影响栖息地关键生境因子变化的同时，如何影 响底栖动物的群落结构特征, 还需要进一步研究。

本文以典型的潮沟水系为研究对象，研究从源头到支流产生的潮沟纵向水文连通强 度差异，对大型底栖动物群落分布以及生物多样性的影响，有助于深人了解湿地水文连

收稿日期：2019-03-10；修订日期：2019-06-13

基金项目：中国工程院咨询研究项目（2018-XZ-14）; 国家重点研发计划（2017YFC0505906); 国家自然科学基金项 目 $(51639001)$

作者简介: 王新艳 (1996- ), 女, 山东临沂人, 博士研究生, 主要从事滨海湿地生态修复研究。

E-mail: WangXinyanwest@126.com

通讯作者：崔保山（1967- ), 男, 河北沽源人，博士，教授，主要从事湿地生态过程与环境响应研究。

E-mail: cuibs@bnu.edu.cn 
通对生物连通的作用机制，为滨海湿地的保护和恢复提供重要的参考。

\section{1 研究方法与数据来源}

\section{1 研究区概况}

研究区（图 1）位于山东省东营市黄河三角洲国家级自然保护区内（37 $47^{\prime} 56^{\prime \prime} \sim 37^{\circ}$ $\left.48^{\prime} 30^{\prime \prime} \mathrm{N}, 119^{\circ} 05^{\prime} 39^{\prime \prime} \sim 119^{\circ} 06^{\prime} 57^{\prime \prime} \mathrm{E}\right)$ ，属暖温带季风型气候区，四季分明，年平均气温为 $11.9^{\circ} \mathrm{C}$, 年平均降水量为 $592.2 \mathrm{~mm}$, 年平均蒸发量为 $1962.1 \mathrm{~mm}$, 属于半湿润地区。潮水 为不规则的半日潮，人海口附近平均高潮间隙为 $10 \sim 11 \mathrm{~h}$, 平均大潮潮差为 $1.06 \sim 1.78 \mathrm{~m}$, 小潮潮差为 $0.46 \sim 0.78 \mathrm{~m}^{[16]}$ 。湿地天然植被主要以盐地碱蓬（Suaeda salsa）、柽柳（Tamarix chinensis) 和芦苇 (Phragmites communis) 为主。该区域潮沟水系发育成熟，构成交 错复杂的潮沟水系网络。

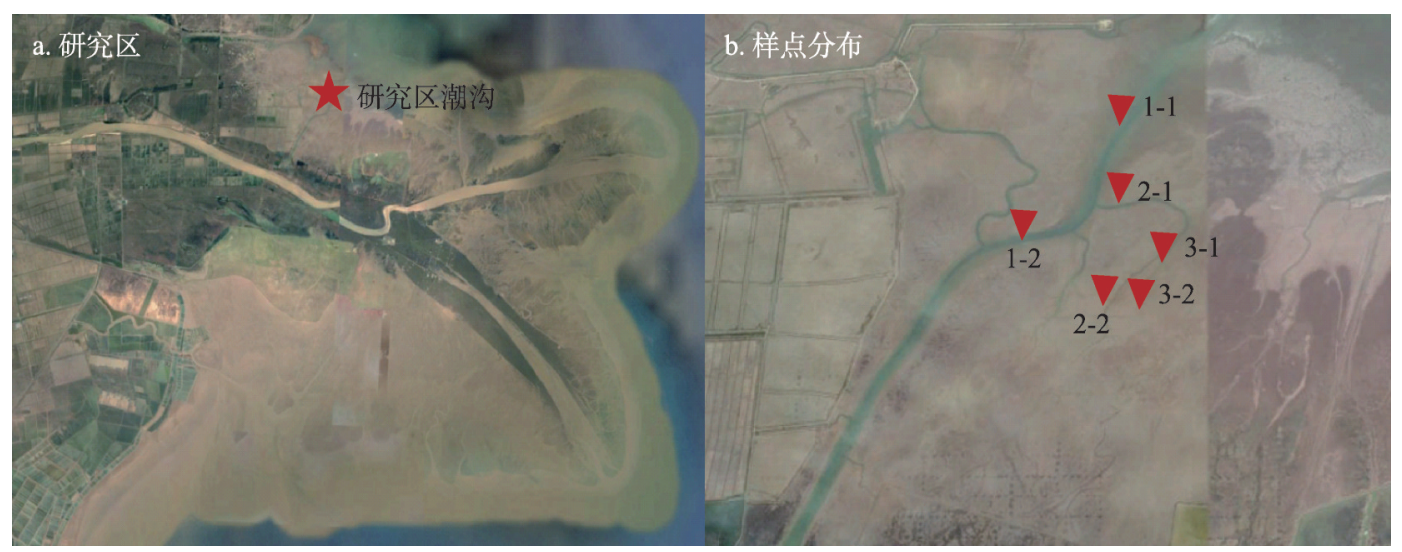

图 1 研究区与样点分布

Fig. 1 Location of the study site and distribution of sampling points

\section{2 潮沟选取}

本文中潮沟的水文连通主要考虑由海向陆的 纵向连通，在研究区域内由海向陆选取三条水文 连通强度差异明显的潮沟（图 2), 潮沟 2 是潮沟 1 的一个分支，潮沟 3 是潮沟 2 的一个分支。选取的 三条潮沟理化性质指标如下表所示（表 1)。高程 为潮沟起点高程, 利用中海达 v9GPS 动态测量测 绘仪器采集; 断面面积为潮沟起点断面面积，利 用直尺测量断面长宽，乘积即为断面面积; 流量 利用手持式 ADV 流速流量测量仪测定；盐度采用 盐度计（JENCO 3010M）测定；可溶性无机氮采

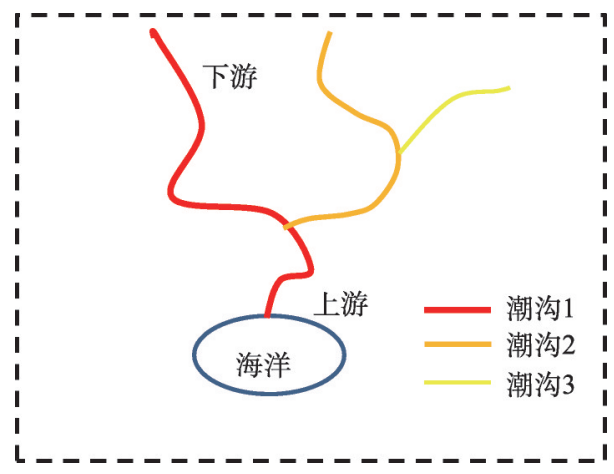

图 2 潮沟模式

Fig. 2 The pattern diagram of tidal channels 用过硫酸钾一紫外分光光度仪比色法测定；总磷采用钼酸铵分光光度法测定。

可以看出，断面面积和流量从潮沟 1 到潮沟 3 依次递减，高程从潮沟 1 到潮沟 3 依次 递增，因此根据潮沟水文连通强度的相关研究 ${ }^{[17]}$ ，可以认为水文连通强度为潮沟 $1>$ 潮沟 $2>$ 潮沟 3 。 


\section{表 1 潮沟理化性质指标}

Table 1 Physical characteristics of tidal channels

\begin{tabular}{lccc}
\hline \multicolumn{1}{c}{ 理化性质 } & 潮沟 1 & 潮沟 2 & 潮沟 3 \\
\hline 高程 $/ \mathrm{m}$ & 0.87 & 1.14 & 1.36 \\
断面面积 $/ \mathrm{m}^{2}$ & 79.75 & 32.50 & 25.53 \\
流量 $/\left(\mathrm{m}^{3} / \mathrm{s}\right)$ & $1.51 \pm 0.14$ & $0.97 \pm 0.33$ & $0.25 \pm 0.21$ \\
盐度 $/ \mathrm{ppt}$ & $19 \sim 23$ & $19 \sim 23$ & $19 \sim 23$ \\
可溶性无机氮 $/(\mu \mathrm{mol} / \mathrm{L})$ & $1.47 \pm 0.13$ & $1.41 \pm 0.22$ & $1.42 \pm 0.19$ \\
总磷 $/(\mu \mathrm{mol} / \mathrm{L})$ & $0.22 \pm 0.03$ & $0.24 \pm 0.13$ & $0.21 \pm 0.21$ \\
\hline
\end{tabular}

\section{3 样品采集与处理}

于 2015 年 6 月在选取的三条潮沟上下游各设置一个样点，共六个样点（图 1）。1-1、 $1-2$ 分别为潮沟 1 上游和下游， $2-1 、 2-2$ 分别为潮沟 2 上游和下游，3-1、3-2 分别为潮沟 3 上游和下游。每个样点随机采集 16 18 个大型底栖动物样品。每个样品用面积为 $0.05 \mathrm{~m}^{2}$ 的采泥器采集 $20 \mathrm{~cm}$ 深土壤，通过 $0.5 \mathrm{~mm}$ 套篮洗出大型底栖动物，然后用 $10 \%$ 的福尔马 林固定。样品采集后, 带回实验室, 全部样品在显微镜下观察, 将大型底栖动物鉴定到 种, 计数, 用滤纸吸干后重量用千分之一的电子天平称量, 软体动物带壳称重, 并换算 成单位面积的生物量 $\left(\mathrm{g} / \mathrm{m}^{2}\right)$ 和栖息密度 $\left(\mathrm{ind} / \mathrm{m}^{2}\right)$ 。

\section{4 统计分析}

\section{4 .1 计算方法}

为了研究不同潮沟大型底栖动物群落特征和生物多样性的变化, 采用生物多样性指 数 ${ }^{[11]}$ (Margalef种类丰度指数 $S 、$ Shannon-Wiener指数 $H^{\prime}$ 和 Pielou 均匀度指数 $J$ ) 来表示大 型底栖动物的种类丰富程度和分布的均匀性，并采用物种优势度来表示群落的优势种， 计算公式如下:

$$
\begin{gathered}
Y=\left(n_{i} / N\right) \times f_{i} \\
S=(S-1) / \ln N \\
H^{\prime}=-\sum_{i=1}^{S} P_{i} \times \ln P_{i} \\
J=\left(-\sum_{i=1}^{S} P_{i} \times \ln P_{i}\right) / \ln S
\end{gathered}
$$

式中: $Y$ 表示物种优势度, 当 $Y>0.02$ 时, 该种即为优势种 ${ }^{[18]} ; f_{i}$ 为该种在各样地出现的频 率; $S$ 为总物种数; $P_{i}$ 为第 $i$ 种的个体数占总个体数的比例; $n_{i}$ 为第 $i$ 种的个体数; $N$ 为所 有种的个体密度。

\subsection{2 数据分析}

使用单因素（One-way ANOVA）方差分析，比较不同潮沟和上下游间大型底栖动物 不同类群密度和生物量的差异。后续多重比较采用最小显著性差异法 (LSD) 检验, 差 异显著定义为 $P<0.05$ 。使用㝋余分析 (Redundancy Analysis, RDA), 检验不同类群的密 度与潮沟理化性质之间的相关性。使用 SPSS 20.0 分析数据和 Origin Pro 8绘制图表。

\section{2 结果分析}

\section{1 潮沟大型底栖动物的种类组成和群落优势种}

\subsection{1 大型底栖动物种类组成}

在三条潮沟进行采样共捕获大型底栖动物 6 个类别, 共 52 种, 其中纽形动物 1 种, 
占总种数的 $1.92 \%$; 寡毛类 1 种，占总种数的 $1.92 \%$; 多毛类 21 种，占总种数的 $40.38 \%$; 软体动物 19 种，占总种数的 $36.54 \%$; 昆虫纲 1 种，占总种数的 $1.92 \%$; 甲壳类 9 种，占总种数的 $17.32 \%$ （表 2)。多毛类和软体动物是构成潮沟底栖动物群落的主要种 类，其次是甲壳类。潮沟 2 中大型底栖动物种类数量最高，潮沟 1 和潮沟 3 种类数相同。 除潮沟 1 外，潮沟 2 和潮沟 3 均为上游底栖动物种类数高于下游种类数。

\section{表 2 不同潮沟中大型底栖动物群落的物种数量组成}

Table 2 Species composition of macrobenthos communities in different tidal channels

(种)

\begin{tabular}{|c|c|c|c|c|c|c|c|c|}
\hline 潮沟 & 上下游 & 纽形动物 & 塞毛类 & 多毛类 & 软体动物 & 昆虫纲 & 甲壳类 & 合计 \\
\hline \multirow[t]{2}{*}{ 潮沟 1} & 上游 & 0 & 1 & 9 & 4 & 1 & 1 & 16 \\
\hline & 下游 & 0 & 1 & 12 & 11 & 0 & 3 & 27 \\
\hline \multicolumn{2}{|c|}{ 总和 } & 0 & 1 & 13 & 12 & 1 & 4 & 31 \\
\hline \multirow[t]{2}{*}{ 潮沟 2} & 上游 & 1 & 1 & 14 & 15 & 0 & 4 & 35 \\
\hline & 下游 & 0 & 1 & 9 & 10 & 0 & 4 & 24 \\
\hline \multicolumn{2}{|c|}{ 总和 } & 1 & 1 & 17 & 17 & 0 & 6 & 42 \\
\hline \multirow[t]{2}{*}{ 潮沟 3} & 上游 & 1 & 1 & 10 & 11 & 0 & 4 & 27 \\
\hline & 下游 & 1 & 1 & 8 & 8 & 0 & 4 & 22 \\
\hline \multicolumn{2}{|c|}{ 总和 } & 1 & 1 & 12 & 11 & 0 & 6 & 31 \\
\hline \multicolumn{2}{|c|}{ 总种数 } & 1 & 1 & 21 & 19 & 1 & 9 & 52 \\
\hline
\end{tabular}

\subsection{2 大型底栖动物群落优势种}

根据物种优势度计算公式，得到三条潮沟上下游的优势种情况（表 3)。潮沟的优势 种主要以多毛类和软体动物为主, 种类有霍甫水丝蚓、寡节甘吻沙虫、中蚓虫、日本刺 沙寔、沙蚕科一种、海稚虫科一种和江户明妲蛤。日本刺沙寔的优势度显著高于其他几 个物种，在各个潮沟均为优势种。潮沟上下游间，上游的优势种种类数要多于下游。

\section{表 3 不同潮沟中大型底栖动物群落的优势种}

Table 3 Dominant species of macrobenthos communities in different tidal channels

\begin{tabular}{|c|c|}
\hline 潮沟 & 优势种 \\
\hline 潮沟 1 上游 & 霍甫水丝蚓、中蚓虫、日本刺沙盍、海稚虫科一种 \\
\hline 潮沟 1 下游 & 寡节甘吻沙虫、中蚓虫、日本刺沙虫、海稚虫科一种 \\
\hline 潮沟 2 上游 & 塞节甘吻沙蚕、中蚓虫、日本刺沙寔、海稚虫科一种、江户明樱蛤 \\
\hline 潮沟 2 下游 & 寡节甘吻沙虫、中蚓虫、日本刺沙蚕、海稚虫科一种 \\
\hline 潮沟 3 上游 & 寡节甘吻沙蚕、中蚓虫、日本刺沙虫、海稚虫科一种、江户明樱蛤 \\
\hline 潮沟 3 下游 & 寡节甘吻沙虫、日本刺沙虫 \\
\hline 潮沟总和 & 霍甫水丝蚓、塞节甘吻沙虫、中蚓虫、日本刺沙虫、沙虫科一种、海稚虫科一种、江户明樱蛤 \\
\hline
\end{tabular}

\section{2 大型底栖动物密度及生物量}

大型底栖动物在不同潮沟间种类和分布不同，密度和生物量也存在一定的差异。三 条潮沟的大型底栖动物总密度和总生物量如图 3a、图 $3 \mathrm{~b}$ 所示。大型底栖动物的总密度为 潮沟 1 高于潮沟 2 和潮沟 3 , 总生物量为潮沟 2 高于潮沟 3 和潮沟 1 。

沿同一潮沟的纵向即上下游，大型底栖动物的密度和生物量也存在着差异（图 $4 \mathrm{a}$ 、 图 4b)。除潮沟 1 上游大型底栖动物总密度高于下游, 潮沟 2 上游总生物量高于下游外, 

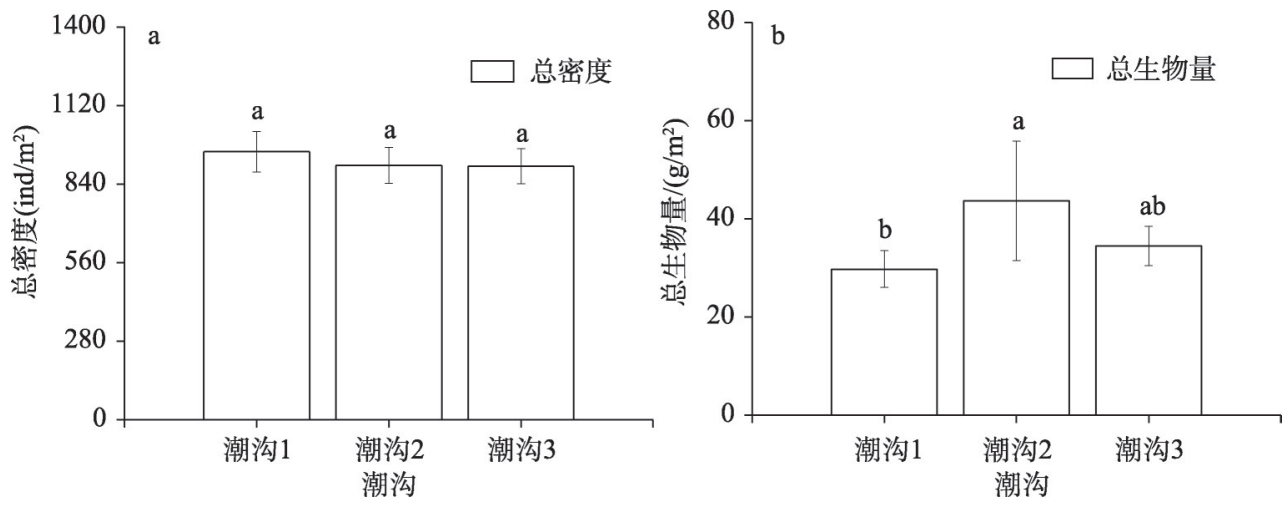

图 3 三条潮沟大型底栖动物的总密度和总生物量

Fig. 3 Total density and biomass of macrobenthos in three tidal channels
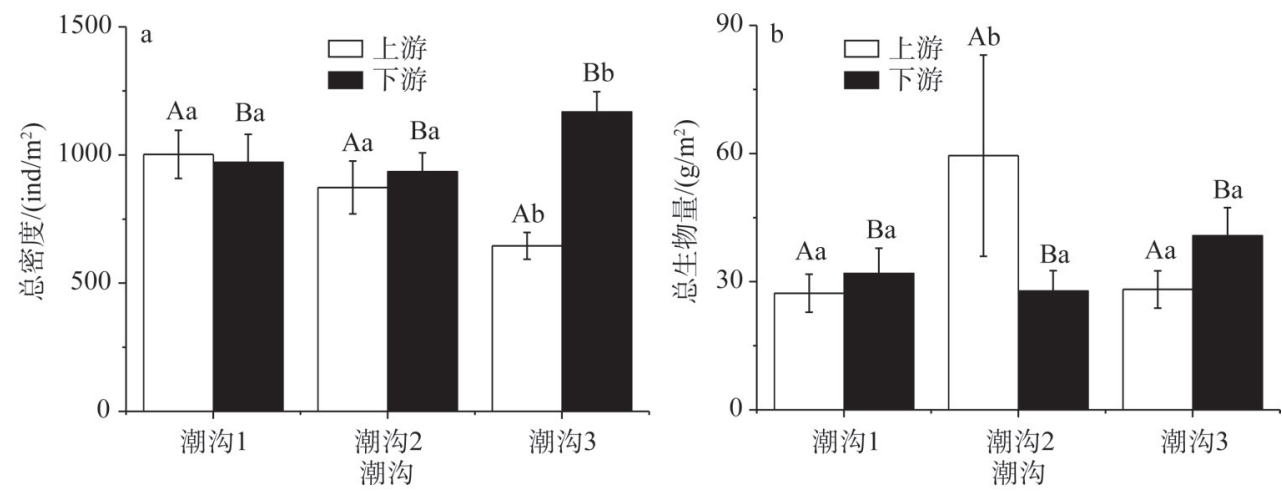

图 4 潮沟上下游大型底栖动物密度和生物量

Fig. 4 Total density and biomass of macrobenthos in the up and down stream of tidal channel

其他上下游的总密度和总生物量均为下游高于上游。

大型底栖动物的不同类群在不同潮沟间的密度和生物量如下图所示（图 5a、图 5b)， 可以看出，多毛类和软体动物的密度和生物量显著高于其他类群，甲壳类和其他类群所

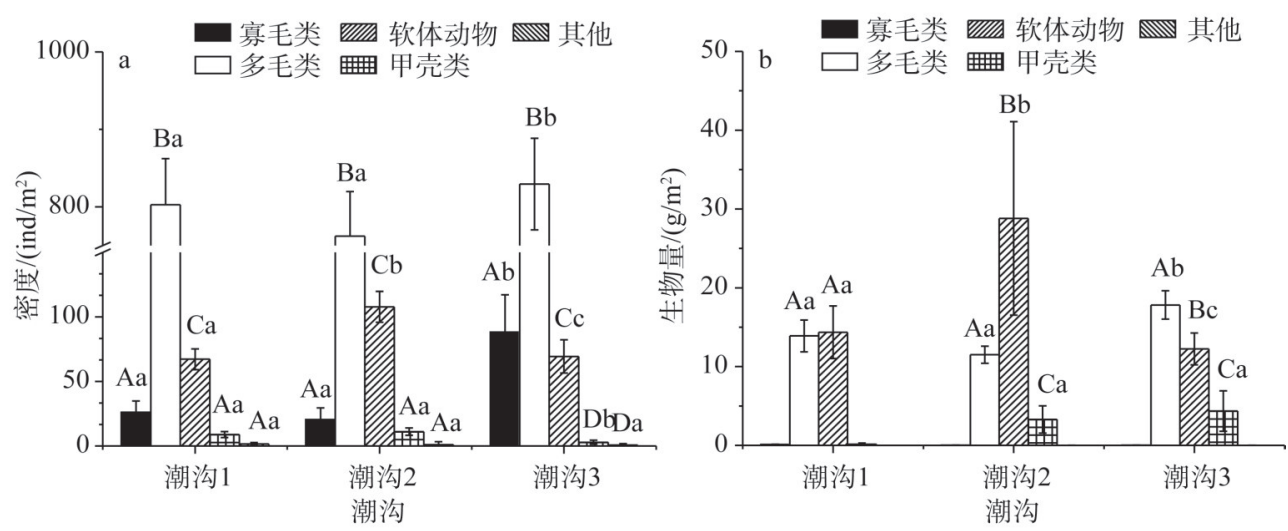

图 5 不同类群的大型底栖动物密度和生物量

Fig. 5 Density and biomass of macrobenthos in different groups 
占的比例很小; 不同类群的密度和生物量在不 同潮沟间也有差异，寡毛类和多毛类在潮沟 3 的分布高于潮沟 1 和潮沟 2 , 而软体动物和甲 壳类的分布则有所不同，软体动物为潮沟 2 的 密度和生物量最高, 甲壳类为潮沟 1 的密度高 于潮沟 2 和潮沟 3 。

\section{3 大型底栖动物群落多样性}

生物多样性指数的结果（Margalef种类丰 度指数 $S$ 、Shannon-Wiener 指数 $H^{\prime}$ 和 Pielou 均 匀度指数 $J$ ) 见图 6, 可以看出 Margalef种类丰 度指数 $S$ 与 Shannon-Wiener 指数 $H^{\prime}$ 变化趋势相 近似, 潮沟 1 下游高于上游, 潮沟 2 和潮沟 3 上游高于下游; Pielou 均匀度指数 $J$ 在不同潮 沟间和上下游间差异不明显; 总的来看, 潮沟

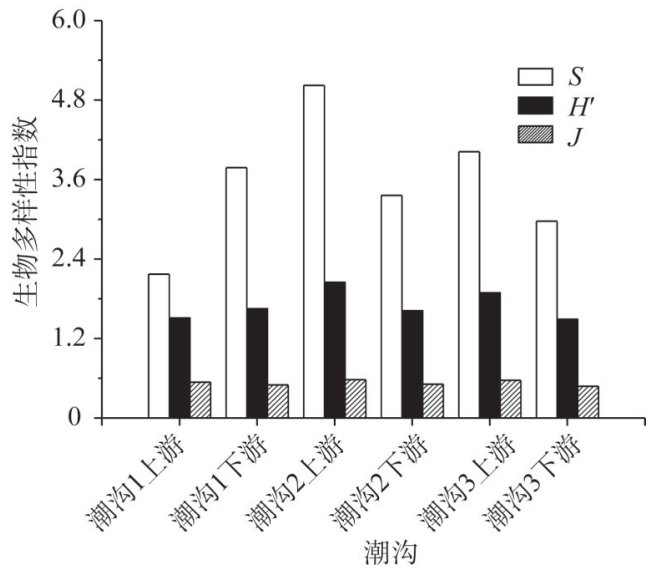

图 6 不同潮沟大型底栖动物生物多样性指数

Fig. 6 Biodiversity index of macrobenthos in different tidal channels

2 的底栖动物生物多样性高于潮沟 1 和潮沟 3 ; 并且潮沟 2 的上游物种种类最多, 分布最 均匀。

\section{3 结论与讨论}

\section{1 结论}

本文以三条水文连通强度差异明显的潮沟为研究对象，调查不同潮沟的大型底栖动 物群落的种类、优势种、密度、生物量和多样性等指标，分析水文连通强度对大型底栖 动物的分布特征和生物多样性的影响。研究证明了潮沟水文连通对大型底栖动物生物连 通的影响, 即总体来说随着水文连通强度的增强, 大型底栖动物的总密度呈上升趋势, 生物多样性更加丰富, 分布更加均匀。并且研究揭示了大型底栖动物不同类群由于生活 习性和生理结构的不同，对水文连通强度不同的区域产生的适应性差异，有助于深人了 解湿地水文连通对生物连通的作用机制，为滨海湿地的保护和恢复提供重要的参考。

\section{2 讨论}

\section{2 .1 大型底栖动物在潮沟上下游的分布特征}

沿同一潮沟的纵向，由于上游更靠近主流，其水文连通强度要高于下游。从上述结 果可以看出, 除潮沟 1 外, 潮沟 2 和潮沟 3 上游的大型底栖动物的总密度和总生物量普遍 高于下游, 并且生物多样性指数（Margalef种类丰度指数 $S$ 、Shannon-Wiener 指数 $H^{\prime}$ 和 Pielou均匀度指数 $J$ ) 也均为上游高于下游。可以看出, 潮沟 2 和潮沟 3 上游由于水文连 通强度大，与下游相比大型底栖动物的数量和种类更为丰富。潮沟 1 上游可能由于靠近 源头, 水动力条件尤为强烈, 潮水冲刷强度大, 不利于大型底栖动物定居, 所以下游的 底栖动物分布更广。

\subsection{2 不同潮沟水文连通差异对大型底栖动物生物连通的影响}

总的来看，大型底栖动物的总密度和总生物量在不同潮沟之间有明显差异，总密度 由潮沟 1 到潮沟 3 呈现降低的趋势, 即随着水文连通强度的减弱, 大型底栖动物总密度呈 下降的趋势。由于不同潮沟的优势种不同，并且个体间生物量存在差异，导致不同潮沟 
间的生物量也存在着差异，潮沟 2 由于软体动物占优势，所以生物量最高。从潮沟 1 到潮 沟 3, 潮沟断面面积减小, 流量逐渐变小，水体和土壤中的营养物质含量下降，底栖动 物的生长和分布受到限制。潮沟 2 的群落多样性要高于潮沟 1 和潮沟 3 , 这可能是由于潮 沟 2 水体中的氮磷含量较高，水文连通强度也较大，在双重作用下，更有利于植物的定 植和生物的繁衍。因此, 中等水文连通强度的区域, 可能生物的分布更均匀, 生物多样 性更高, 国内外对泛滥平原底栖动物的研究也有类似的结论 ${ }^{[19-21]}$ 。

\subsection{3 大型底栖动物不同类群对水文连通的响应}

大型底栖动物的生长分布, 受环境因子 的作用显著, 如盐度、无机碳含量、总磷含 量、流速等环境因子都会对底栖动物的生 长、繁殖和存活产生影响 ${ }^{[22-27]}$ 。圥余分析 （RDA）结果表明，5个环境因子解释了 $100 \%$ 的 大型底栖动物不同类群总密度的差异（图 7)。 第一排序轴的特征值为 0.751 , 第二排序轴的 特征值为 0.249 。

在水文过程的作用下，潮沟上下游和不 同潮沟之间环境特征有很大差异，大型底栖 动物的不同类群由于生活习性和生理结构的 差异，导致其对不同环境的适应性也存在差 异。靠近潮沟口, 水文连通强的区域, 受潮 汐冲刷比较强烈, 土壤颗粒较大, 土壤和水 体盐度较高, 更有利于盐沼植被的定植 ${ }^{[28-29]}$, 因此个体较小、活动范围比较广的, 需要靠

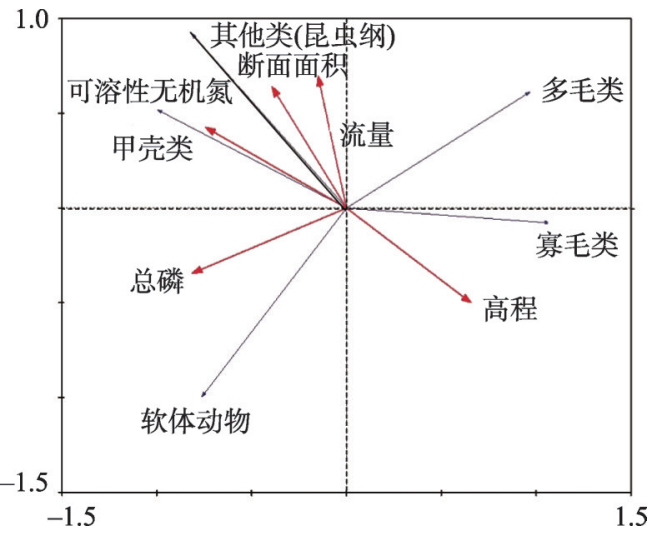

注: 红色箭头、黑色箭头分别表示大型底栖动物 类群的总密度和环境因子。

图 7 大型底栖动物类群的总密度和环境 因子的㝋余分析

Fig. 7 RDA triplot of total density of macrobenthos groups and environment parameters 植被庇护的甲壳类在该区域（潮沟 1）占优势 ${ }^{[30]}$ 。潮沟的支流（潮沟 3）水文连通强度 弱，冲刷性弱，沉积物大量聚集，适合多毛类和寡毛类这种活动范围比较小的底栖动物 类群生存 ${ }^{[31-32]}$ 。软体动物中双壳类占优势, 主要以滤食性动物为主, 在营养物质含量较丰 富, 水体流量较大, 淹水频率较高的区域分布广泛 ${ }^{[33]}$, 因此水文连通强度较高、总磷含 量丰富的潮沟 2 , 软体动物分布多。由此可以看出, 湿地的水文过程使环境因子发生变 化，由于大型底栖动物对环境的适应性存在差异，进而影响生物的生长繁殖和迁移扩散。

\section{参考文献(References):}

[1] 张晓龙, 李培英, 李萍, 等. 中国滨海湿地研究现状与展望. 海洋科学进展, 2005, 23(1): 87-95. [ZHANG X L, LI P Y, LI P, et al. Present conditions and prospects of study on coastal wetlands in China. Advances in Marine Science, 2005, 23 (1): 87-95.]

[2] 李伟, 崔丽娟, 赵欣胜, 等. 中国滨海湿地及其生态系统服务功能研究概述. 林业调查规划, 2014, 39(4): 24-30. [LI W, CUI L J, ZHAO X S, et al. An overview of Chinese coastal wetland and their ecosystem services. Forest Inventory and Planning, 2014, 39(4): 24-30.]

[3] BARBIER E B. Valuing ecosystem services for coastal wetland protection and restoration: Progress and challenges. Resources, 2013, 2(3): 213-230.

[4] LEE S Y, DUNN R J K, YOUNG R A, et al. Impact of urbanization on coastal wetland structure and function. Austral Ecology, 2006, 31(2): 149-163. 
[5] WESTON N B. Declining sediments and rising seas: An unfortunate convergence for tidal wetlands. Estuaries and Coasts, 2014, 37(1): 1-23.

[6] 崔保山, 蔡燕子, 谢活, 等. 湿地水文连通的生态效应研究进展及发展趋势. 北京师范大学学报: 自然科学版, 2016, 52(6): 738-746. [CUI B S, CAI Y Z, XIE T, et al. Ecological effects of wetland hydrological connectivity: Problems and prospects. Journal of Beijing Normal University, 2016, 52(6): 738-746.]

[7] 张梦嫚, 吴秀芹. 近 20 年白洋淀湿地水文连通性及空间形态演变. 生态学报, 2018, 38(12): 4205-4213. [ZHANG M, WU X Q. Changes in hydrological connectivity and spatial morphology of Baiyangdian wetland over the last 20 years. Acta Ecologica Sinica, 2018, 38(12): 4205-4213.]

[8] 高常军, 高晓翠, 贾朋. 水文连通性研究进展. 应用与环境生物学报, 2017, 23(3): 586-594. [GAO C J, GAO X C, JIA P. Summary comments on hydrologic connectivity. Chinese Journal of Applied \& Environmental Biology, 2017, 23(3): 586-594.]

[9] ZOU L, YAO X, YAMAGUCHI H, et al. Seasonal and spatial variations of macro benthos in the intertidal mudflat of southern Yellow River Delta, China in 2007/2008. Journal of Ocean University of China, 2018, 17(2): 437-444.

[10] 胡知㸠. 环境干扰对滩涂湿地大型底栖动物群落结构的影响. 金华: 浙江师范大学, 2009. [HU Z Y. The ecological impact and effect of habitat disturbance on microbenthic community in tidal flat wetland. Jinhua: Zhejiang Normal University, 2009.]

[11] 胡知沸, 鲍毅新, 葛宝明, 等. 围垦滩涂潮沟秋季大型底栖动物群落和生态位分析. 动物学报, 2006, 52(4): 800-809. [HU Z Y, BAO Y X, GE B M, et al. Macrobenthic community and niche analysis of creeks during autumn in diked tidal flat. Acta Zoologica Sinica, 2006, 52(4): 800-809.]

[12] SCHUCKEL U, BECK M, KRONCKE I. Macrofauna communities of tidal channels in Jade Bay (German Wadden Sea): Spatial patterns, relationships with environmental characteristics, and comparative aspects. Marine Biodiversity, 2015, 45(4): 841-855.

[13] SEO J Y, LIM H S, CHOI J W. Distribution patterns of macrobenthic fauna communities in Deukryang Bay, one of the environment conservation areas of Korea. Ocean Science Journal, 2014, 49(2): 97-113.

[14] 储忝江, 盛强, 王思凯, 等. 沿潮沟级别大型底栖动物群落的次级生产力空间变异. 复旦学报: 自然科学版, 2016, 55 (4): 460-470. [CHU T J, SHENG Q, WANG S K, et al. Spatial variability of macrobenthic secondary production along a creek-order gradient. Journal of Fudan University, 2016, 55(4): 460-470.]

[15] 宋慈玉, 储忝江, 盛强, 等. 长江口盐沼分级潮沟系统中大型底栖动物群落结构特征. 复旦学报: 自然科学版, 2011, 50(3): 253-259. [SONG C Y, CHU T J, SHNG Q, et al. Macrobenthos communities in salt marshes of the Yangtze River estuary along a creek-order gradient. Journal of Fudan University, 2011, 50(3): 253-259.]

[16] 王一鸣. 黄河水沙变化及其对黄河三角洲变化的影响分析. 北京: 中国科学院大学, 2018. [WANG Y M. Analysis on the water and sediment variation in Yellow River and its influence on the change of Yellow River Delta. Beijing: University of Chinese Academy of Sciences, 2018.]

[17] 骆梦, 王青, 邱冬冬, 等. 黄河三角洲典型潮沟系统水文连通特征及其生态效应. 北京师范大学学报: 自然科学版, 2018, 54(1): 17-24. [LUO M, WANG Q, QIU D D, et al. Hydrological connectivity characteristics and ecological effects of a typical tidal channel system in the Yellow River Delta. Journal of Beijing Normal University, 2018, 54(1):1724.]

[18] 徐兆礼, 陈亚篗. 东黄海秋季浮游动物优势种聚集强度与鲐鲐渔场的关系. 生态学杂志, 1989, 4: 13-15, 19. [XU Z L, CHEN Y Q. Aggregated intensity of dominant species of zooplankton in autumn in the East China Sea and Yellow Sea. Chinese Journal of Ecology, 1989, 4: 13-15, 19.]

[19] 潘保柱, 王海军, 梁小民, 等. 长江故道底栖动物群落特征及资源衰退原因分析. 湖泊科学, 2008, 20(6): 806-813. [PAN B Z, WANG H J, LIANG X M, et al. Macrozoobenthos in Yangtze oxbows: Community characteristics and causes of resources decline. Journal of Lake Sciences, 2008, 20(6): 806-813.]

[20] OBRDLIK P, FUCHS U. Surface water connection and the macrozoobenthos of two types of floodplains on the Upper Rhine. Regul Rivers Res Manag, 1991, 6: 279-288.

[21] TOCKNER K, SCHIEMER F, BAUMGARTNER C, et al. The Danube restoration project: Species diversity patterns across connectivity gradients in the floodplain system. Regul Rivers Res Manag, 1999, 15: 245-258. 
[22] 周治东, 张跃平, 李海平, 等. 福建省大港湾大型底栖动物的群落特征. 应用海洋学学报, 2016, 35(4): 529-536. [ZHOU Z D, ZHANG Y P, LI H P, et al. Macrobenthos ecological study in Dagang Bay, Fujian province. Journal of Applied Oceanography, 2016, 35(4): 529-536.]

[23] 王志忠, 张金路, 杜兴华, 等. 黄河口底栖动物群落特征及其环境质量评价. 生态科学, 2014, 33(2): $269-275$. [WANG Z Z, ZHANG J L, DU X H, et al. Community characteristics of macrozoobenthos and environmental quality assessment of the Yellow River Estuary. Ecological Science, 2014, 33(2): 269-275.]

[24] 李中宇, 陈威, 胡显安, 等. 松花江底栖动物分布规律及与理化评价差异研究. 中国环境监测, 2018, 34(3): 59-67. [LI Z Y, CHEN W, HU X A, et al. Study on the distribution law and the difference with physicochemical evaluation of zoobenthos in Songhua River. Environmental Monitoring in China, 2018, 34(3): 59-67.]

[25] 杨磊, 黄瑞换, 卢占晖, 等. 金塘岛海域大型底栖动物分布及其与环境因子的关系. 浙江海洋大学学报: 自然科学 版, 2017, 36(4): 295-301, 307. [YANG L, HUANG R H, LU Z H, et al. The distribution of macrobenthos and the relationship with environmental factors in the waters around Jintang Island. Journal of Zhejiang Ocean University, 2017, 36 (4): 295-301, 307.]

[26] 张舒怡. 大亚湾大型底栖动物群落及其环境影响因子研究. 厦门: 国家海洋局第三海洋研究所, 2017. [ZHANG S Y. Study on macrobenthos communities and its environmental impact factors in Daya Bay. Xiamen: Third Institute of Oceanography, State Oceanic Administration, 2017.]

[27] 张均龙. 黄海大型底栖生物多样性与群落结构的研究. 青岛: 中国科学院研究生院海洋研究所, 2012. [ZHANG J L. Biodiversity and community structure of macrobenthos in the Yellow Sea. Qingdao: Institute of Oceanology, Chinese Academy of Sciences, 2012.]

[28] 贺强, 安渊, 崔保山. 滨海盐沼及其植物群落的分布与多样性. 生态环境学报, 2010, 19(3): 657-664. [HE Q, AN Y, CUI B S. Coastal salt marshes and distribution and diversity of salt marsh plant communities. Ecology \& Environmental Sciences, 2010, 19(3): 657-664.]

[29] 赵欣胜,崔保山, 孙涛, 等.黄河三角洲潮沟湿地植被空间分布对土壤环境的响应.生态环境学报, 2010, 19(8): 18551861. [ZHAO X S, CUI B S, SUN T, et al. The relationship between the spatial distribution of vegetation and soil environmental factors in the tidal creek areas of the Yellow River Delta. Ecology \& Environmental Sciences, 2010, 19(8): 1855-1861.]

[30] 张爱静. 水文过程对黄河口湿地景观格局演变的驱动机制研究. 北京: 中国水利水电科学研究院, 2013. [ZHANG A J. Studies on the driving mechanism of hydrological processes on the landscape pattern evolution of the Yellow River Estuary wetland. Beijing: China Institute of Resources and Hydropower Research, 2013.]

[31] 于政达. 河流和湖泊底栖动物分布的影响因素及稀有种去除对多样性指数的影响. 济南: 山东大学, 2017. [YU Z D. Influencing factors of distribution pattern of macroinvertebrate and responses of biological indices to rare taxa excluding in rivers and lakes. Jinan: Shandong University, 2017.]

[32] 唐盟. 福建三沙湾养殖活动对底栖环境及多毛纲动物群落结构影响研究. 上海: 上海海洋大学, 2017. [TANG M. Environmental impacts of mariculture on sedimentary variables and polychaete community structure in Sansha Bay, Fujian province. Shanghai: Shanghai Ocean University, 2017.]

[33] 李宝泉, 李新正, 于海燕, 等. 胶州湾底栖软体动物与环境因子的关系. 海洋与湖沼, 2005, 36(3): 193-198. [LI B Q, LI X Z, YU H Y, et al. Macrobenthic Mollusca fauna and its relationship to environment factors in Jiaozhou Bay. Oceanologia et Limnologia Sinica, 2005, 36(3): 193-198.] 


\title{
Influence of hydrological connectivity of coastal wetland on the biological connectivity of macrobenthos in the Yellow River Estuary
}

\author{
WANG Xin-yan, YAN Jia-guo, BAI Jun-hong, CUI Bao-shan \\ (State Key Laboratory of Water Environment Simulation, School of Environment, Beijing \\ Normal University, Beijing 100875, China)
}

\begin{abstract}
Coastal wetland is the transitional area between land and sea, with high habitat complexity, species biodiversity and ecological service functions. However, due to the influence of human activity and climate change, the areas of the wetlands are gradually reduced, and the structure and functions of wetlands such as hydrological connectivity are greatly influenced. In the present work, we selected three typical tidal channels with obvious differences in hydrological connectivity, investigated the macrobenthos community between different tidal channels and analyzed the influence of longitudinal hydrological connectivity on the distribution and diversity (density, biomass and biodiversity) of macrobenthos. A total of 52 species were documented, and the numerically abundant taxonomic groups were Polychaeta and Mollusca; Overall, with the increase of hydrological connectivity, the total density of macrobenthos showed an upward trend; the areas with moderate hydrological connectivity tended to have a higher biodiversity; different groups of macrobenthos showed different density and distribution responding to environmental factors caused by hydrological connectivity; Polychaeta and Oligochaeta were dominant in areas with low hydrological connectivity and Mollusca were dominant in areas with high hydrological connectivity and abundant nutrients; Crustacea were dominant in areas close to the channel source with the highest hydrological connectivity. This study is helpful to understand the mechanism of wetlands hydrological connectivity on biological connectivity, and provide an important reference for the protection and restoration of coastal wetlands.
\end{abstract}

Keyword: coastal wetland; hydrological connectivity; macrobenthos; biological connectivity 